\title{
Microbial Production of Natural Gas from Coal and Organic-Rich Shale
}

Natural gas is an important component of the energy mix in the United States, producing greater energy yield per unit weight and less pollution compared to coal and oil. Most of the world's natural gas resource is thermogenic, produced in the geologic environment over time by high temperature and pressure within deposits of oil, coal, and shale. About 20 percent of the natural gas resource, however, is produced by microorganisms (microbes). Microbes potentially could be used to generate economic quantities of natural gas from otherwise unexploitable coal and shale deposits, from coal and shale from which natural gas has already been recovered, and from waste material such as coal slurry. Little is known, however, about the microbial production of natural gas from coal and shale.

Since 2006, the U.S. Geological Survey Energy Resources Program has supported studies of microbial natural gas production from coal and shale. Major goals of this work are to:

1. Examine environmental and geologic conditions (water chemistry, coal type, geologic framework) that promote microbial natural gas production in the field.

2. Determine, by use of laboratory bioreactors, the most effective types of microorganism combinations and the mechanisms they use to convert complex organic molecules in coal and shale to natural gas (fig. 1); the project will develop approaches to increase the rate and yield of microbial natural gas production.

3. Develop a microbiological test (bioassay) to assess the potential of coal and shale for microbial natural gas production.

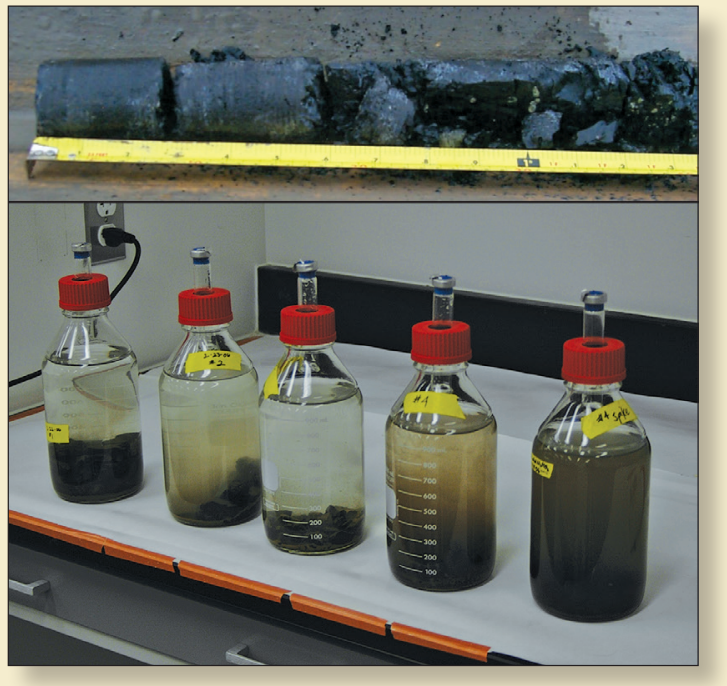

Figure 1. Drill core of coal from Texas (top) used in laboratory bioreactors (bottom) to examine microbial natural gas production.
4. Develop and test, based on laboratory and field results, a field protocol or process that is practical and can be used to stimulate microbes to produce economic quantities of natural gas from coal and shale.

\section{Microbial Natural Gas Production}

The principal component in microbial natural gas is methane gas $\left(\mathrm{CH}_{4}\right)$, and the overall biodegradation process is referred to as methanogenesis. Biodegradation pathways in methanogenesis are complex (fig. 2) and involve different microorganisms acting as a team or consortium. Certain bacteria initiate biodegradation by hydrolytic fermentation, releasing enzymes that break chemical bonds in the geopolymers and release smaller organic molecules into the fluid medium. These smaller organic molecules (alkanes, fatty acids, aromatics) are then utilized by many other types of microorganisms, including syntrophic bacteria that use the byproducts produced by each other. The organisms that produce methane gas in the final step using acetate $\left(\mathrm{C}_{2} \mathrm{H}_{3} \mathrm{O}_{2}^{-}\right)$or carbon dioxide $\left(\mathrm{CO}_{2}\right)$ and hydrogen $\left(\mathrm{H}_{2}\right)$ are the methanogens.

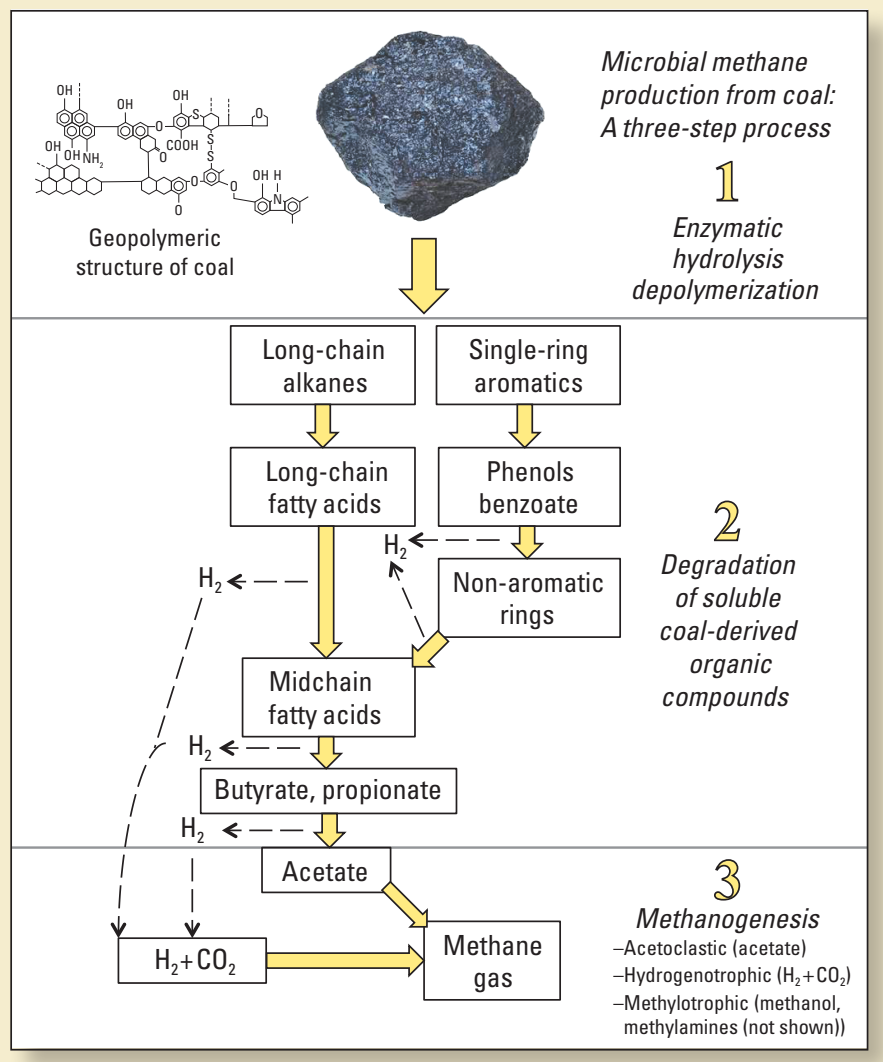

Figure 2. Microbial biodegradation pathway of coal geopolymers to methane gas. 


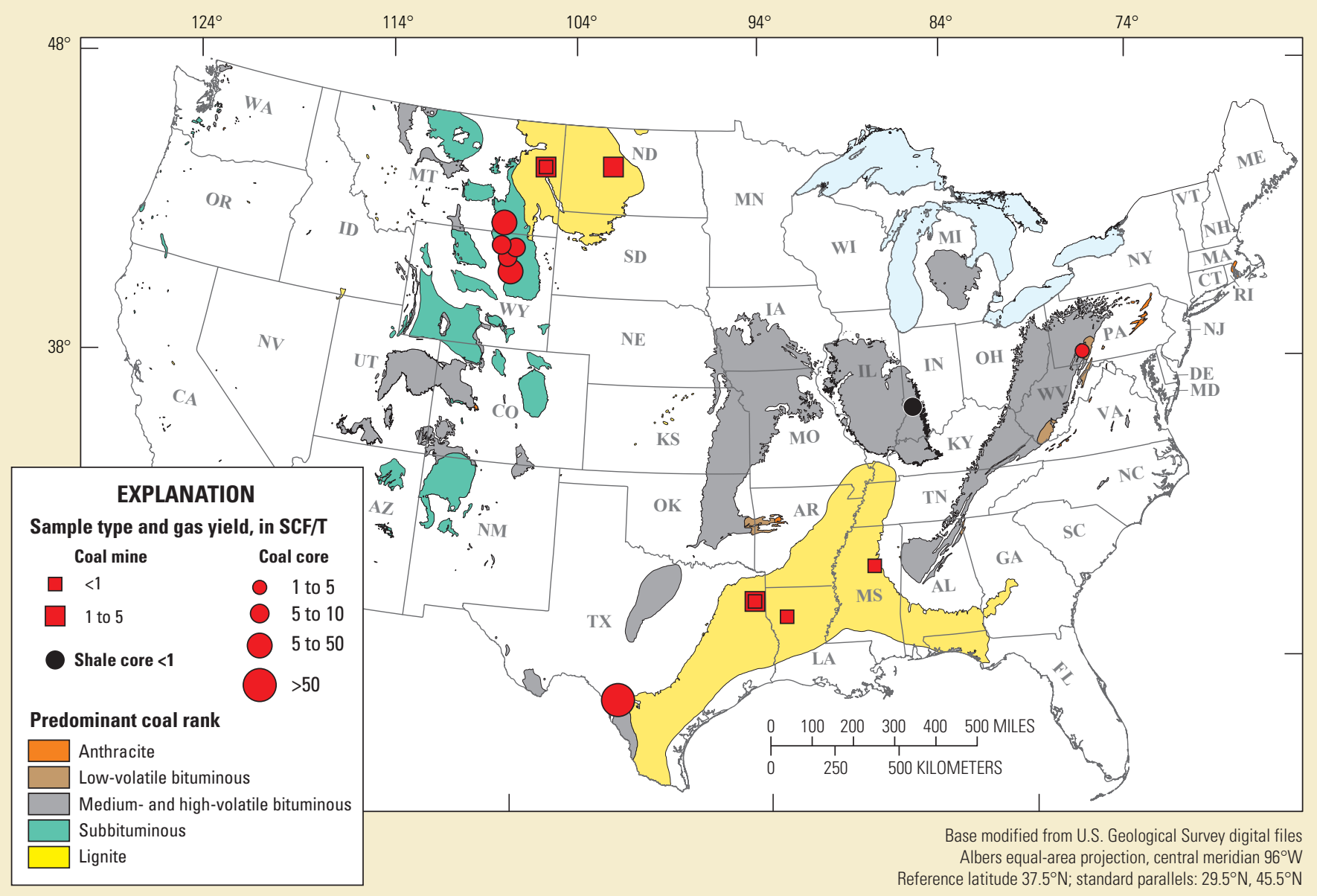

Figure 3. Coal map of the United States showing the location of samples used in the bioassay experiment (modified from East, 2013). SCF/T, standard cubic feet per ton.

\section{Methanogenesis Bioassay}

A bioassay (called WBC-2) was developed to examine the potential of different coals for natural gas production (Jones and others, 2008). The bioassay is a microbial consortium isolated from industrially contaminated wetland sediments; cultured in the laboratory, the bioassay has the capacity to degrade coal to methane gas. This bioassay can be used to evaluate various coals for their potential to produce microbial natural gas, with the Wilcox coal in Texas and the Upper Wyodak coal in the Powder River Basin, Wyoming, having the highest potential (fig. 3).

\section{Enhancement of Biomethanogenesis}

Laboratory investigations are exploring methods for enhancing microbial methane production from coal and shale. Approaches being investigated include (1) adding nutrients to enhance the activity of native populations of microorganisms in coal and shale deposits (biostimulation), (2) adding microorganisms to enhance methane production (bioaugmentation), (3) altering the chemical and physical properties of the coal and shale to increase its availability for microbial degradation, and (4) using various combinations of these approaches. Laboratory protocols that show promising results will be tested in a selected coal bed in the Powder River Basin, Wyoming or Montana, where microbial coal-bed methane has already been identified.
A successful outcome could result in enhanced quantities of microbial natural gas being produced as biomethanogenic approaches are repeated over several cycles.

\section{References Cited}

Jones, E.J.P., Voytek, M.A., Warwick, P.D., Corum, M.D., Cohn, Alexander, Bunnell, J.E., Clark, A.C., and Orem, W.H., 2008, Bioassay for estimating the biogenic methane-generating potential of coal samples: International Journal of Coal Geology, v. 76 , p. $138-150$.

East, J.A., 2013, Coal fields of the conterminous United StatesNational Coal Resource Assessment updated version: U.S. Geological Survey Open-File Report 2012-1205, one sheet, scale 1:5,000,000, available at http://pubs.usgs.gov/of/2012/1205/.

For additional information, contact:

William Orem

U.S. Geological Survey

956 National Center

Reston, VA 20192

Email: borem@usgs.gov

or visit the USGS Energy Resources Program homepage: http://energy.usgs.gov/ 